\title{
Country and Industry Convergence of Equity Markets: International Evidence from Club Convergence and Clustering
}

\author{
Nicholas Apergis \\ Chair and Professor \\ Department of Banking and Financial Management, \\ University of Piraeus \\ Greece \\ Christina Christou \\ Assistant Professor \\ Department of Banking and Financial Management, \\ University of Piraeus \\ Greece \\ Stephen M. Miller* \\ Professor of Economics \\ Department of Economics \\ University of Nevada, Las Vegas \\ U.S.A.
}

July 2012

\begin{abstract}
This study employs the panel convergence methodology developed by Phillips and Sul (2007) to explore the convergence dynamics of international equity markets. The analysis considers both country and industry effects. While traditional portfolio management strategies usually follow a top-down procedure, assuming that country-level effects drive financial aggregates (e.g., stock returns) our empirical results suggest that the equity markets of 33 of the 42 counties in our sample do form a unified convergence club. The empirical findings, however, also show more numerous stock-price convergence clubs in certain industries. That is, country factors play a more important role in explaining the actual convergence in real stock prices than industry factors. Conversely, the volatility of stock prices exhibits much more evidence of convergence than stock prices. These findings should assist portfolio managers in the design and implementation of appropriate portfolio management strategies. Regulatory authorities also can benefit in the design of financial regulation.
\end{abstract}

Keywords: $\quad$ equity markets convergence, international equity markets, industry effects, panel convergence methodology

JEL Classification: C32, C33

* $\quad$ Corresponding author. 


\section{Country and Industry Convergence of Equity Markets: International Evidence from the Club Convergence and Clustering Procedure}

\section{Introduction}

In recent years, researchers pay more attention to the convergence in international equity markets. This increased interest in the convergence process accompanies the elimination of restrictions on banking and securities transactions, the reduction or the abolition of capital restrictions, the harmonization of legal frameworks and accounting systems for financial reporting, and the encouragement of foreign (direct) investments. That is, recent changes international regulations encouraged dramatic increases in capital flows between countries. In frictionless international financial markets, the culmination of the freeing of capital to flow toward the highest return will lead to the convergence of financial markets, including equity markets. Impediments to the free flow of capital, tendencies of financial investors to a home bias, and so on will prevent the ultimate convergence of equity markets, however.

To the extent that convergence in equity markets occurs, the gains from international portfolio diversification will decrease. The countervailing view argues that certain economies retain their individual national economic and financial characteristics, which will prevent equity markets from full convergence (Adler and Dumas, 1983). In other words, impediments to the free flow of capital, tendencies for a home bias, and so on will maintain the possible gains from international portfolio diversification.

Conventional wisdom argues that investors can improve their risk-return efficiency through international diversification (Grubel, 1968; Levy and Sarnat, 1970; Solnik, 1974). Numerous studies (e.g. Bekaert et al., 2009; Carrieri et al., 2008; Eiling and Gerard, 2007; King et al., 1994; Longin and Solnik, 1995) examine how the correlation across countries' equity 
markets change over time for developed and emerging market economies, since relatively low correlation across such markets may signal diversification benefits. Mixed evidence emerges as to the movement in cross-country correlations across international equity markets. Christoffersen et al. (2010) argue that since most studies employ a factor or multivariate volatility model, these mixed results may partly reflect differences in models rather than real differences in correlations.

Eun and Lee (2010) consider international mean-variance convergence, using a Euclidian distance measure. Their findings, which do not depend on model selection, show that the riskreturn characterization for their samples of developed and emerging market economies converge significantly over their sample period (1974 to 2007). They also report that the convergence reflects a declining "country effect", rather than a rising "industry effect". This declining "country effect" implies that convergence of stock markets leads to the fall in the effect of individual country characteristics, whereas the rising "industry effect” implies that convergence of industrial structures across countries as well as a more important industry effect.

This paper re-investigates whether international equity markets exhibit evidence of convergence, where the analysis also distinguishes between country and industry effects as well as returns and volatilities. The paper also departs from the standard approach in the finance literature in testing for convergence and borrows from the literature on the convergence in macroeconomic variables (e.g., convergence of real GDP per capita). While traditional portfolio management strategies usually follow a top-down procedure, assuming that the country effects drive the determination of financial aggregates. This approach, however, receives heavy criticism, since as countries become similar in their industrial structure, a higher degree of industrial stock market convergence will probably occur. Therefore, we explore whether global or local factors determine financial aggregates. International countries exhibit fundamental 
differences in terms of their national stock markets due to the differentiation of certain factors, such as taxation, reporting and accounting standards, legislation, and differences in the pricing of risk. The degree of convergence should differ among financial aggregates across industrial sectors, since idiosyncratic characteristics across industries result in different relative immobilities across-national production frontiers. Such differences appear as profitability differences and these, in turn, appear as stock market return differences. In addition to different production structures, differences in shock volatilities across industrial sectors could explain convergence or divergence patterns. Finally, international deregulation agreements should affect the degree of convergence across sectors, such as the tradable goods or financial sectors.

In macroeconomics, initial empirical tests of the convergence hypothesis, which focuses on real GDP per capita, consider $\beta$-convergence. Without additional control variables, the test considered absolute convergence, whereas with additional control variables, the test examines conditional convergence. Researchers use regressions to test for $\beta$-convergence that generally imply a log-linearized solution to a non-stochastic model with an additive error term.

An alternative view of convergence, $\sigma$-convergence, argues that a group of economies converge when the cross-section variance of the variable under consideration (e.g., real GDP per capita) declines across time. As noted by Bliss (1999, 2000), however, the underlying assumption of an evolving data distribution introduces difficulties in the interpretation of the test distribution under the null. Moreover, the rejection of the $\sigma$-convergence hypothesis does not necessarily mean that economies do not converge; the presence of transitional dynamics in the data can lead to the rejection of the null hypothesis of $\sigma$-convergence.

Critics of $\beta$-convergence argue that if countries converge to a common equilibrium with identical internal structures, then the dispersion of the variable under study should disappear in 
the long-run as all countries converge to the same long-run path. If, however, countries converge to convergence clubs or to their own unique equilibrium, the dispersion of this variable will not approach zero (Miller and Upadhyay, 2002). Moreover, in the latter case of country specific equilibrium, the movements of the dispersion will depend on the initial distribution of the variable under investigation relative to their final long-run outcomes. Overall, these two approaches suffer from specific estimation deficiencies associated with the time series used (Caporale et al., 2009).

Finally, the use of cointegration and unit-root tests for determining convergence confronts the researcher with a number of serious drawbacks. First, these tests fail to detect convergence when more than one equilibria exist. In the framework of Azariadis and Drazen's (1990) theoretical growth model, multiple steady-state equilibria can occur. Durlauf and Johnson (1995) also provide empirical evidence in favor of the presence of converging clubs across countries. Second, if the countries do converge, but the data available to the econometrician reflect a time period in which transitional dynamics prevail, cointegration and unit-root tests may not 'catch' the tendency to converge. Thus, to study the issue of convergence requires that the researcher model both transitional dynamics and long-run behavior together in a consistent framework. Unfortunately, standard existing testing methodologies for convergence fail to account for both regularities and, thus, cannot suitably test real economic convergence.

This paper employs a new methodological approach, which overcomes the abovementioned deficiencies, the panel club convergence and clustering procedure recommended by Phillips and Sul (2007). This methodology possesses several advantages. First, we do not need specific assumptions concerning the stationarity of the variables of interest and/or the existence of common factors. Second, this methodology uses a general form of 
nonlinear time-varying factor models. Third, this approach incorporates the countries' experience in transitional dynamics, while it abstains from the hypothesis of homogeneous technological progress, an assumption extensively employed in the majority of growth studies. This is crucial, since under technological heterogeneity, the examination of either growth convergence or growth determinants by standard panel stationarity tests is not valid (Phillips and Sul, 2006). A number of researchers (e.g., Fritsche and Kuzin, 2008; Caporale et al., 2009) use this methodology to investigate convergence patterns among various markets, such as labor markets and productivity measures.

We apply the Phillips-Sul (2007) methodology to examine the extent of convergence of cross-country equity markets for a sample of developed and emerging market economies. Apergis et al. (2011) apply the Phillips-Sul (2007) methodology to consider the convergence of cross-country equity markets for a sample of developed countries. They also consider whether institutional (political) factors (e.g., democratization, socialist or conservative votes, and so on) associate with the two identified convergence clubs. We extend their analysis by considering a larger sample of countries, including both developed and emerging economies as well as by considering convergence of equity markets for industries. In addition, the paper performs the analysis with disaggregated industry stock price data, since convergence may confine itself to financial aggregates in different sectors of the market. That is, Poterba and Summers (1998) argue that investors may more easily arbitrage profitable opportunities away at the industry level rather than the market level.

Section 2 provides a brief survey of the literature. Section 3 outlines the econometric methodology. Section 4 describes the data and reports the empirical findings. Section 5 concludes. 


\section{Literature Review}

Although most studies support a greater degree of integration among international equity markets in recent years, some differences across areas of the world seem to persist (Dickinson, 2000). Errunza et al. (1999), Arouri (2004), and Jayasuriya and Shambora (2008) show that U.S. investors experienced significant gains by investing in emerging markets, though those gains are steadily shrinking. Leachman and Francis (1995) attribute the growing integration of financial markets to improved policy coordination across different economic areas, especially in foreign exchange markets. Goetzmann et al. (2001) and Hartmann et al. (2003) report that highly integrated equity markets make the international diversification potential very low, when compared to the longer-term history of capital markets. Baca et al. (2000) and Ferreira (2004) also support this view when they confirm that both country and industry correlations fell significantly since their peak levels in 1998.

Adam et al. (2002), Baele et al. (2004), and Portes and Rey (2005) not only organize the different definitions of equity convergence, but also provide evidence about the enhanced role of the common currency within Europe for equity market convergence. Hanousek and Filer (2000) also show that integration strengthened significantly in the new European Union countries. Adjaoute and Danthine (2004), Egert and Kočenda (2007) and Cappiello et al. (2009) also support these findings. Piesse and Hearn (2002) and Cerny (2004) find a weaker degree of integration for the Asian emerging equity markets. By contrast, Yang et al. (2003a) argue that this occurs only over the post-Asian crisis period. Ayuso and Blanco (2000), using a timevarying approach, find a greater degree of integration, at least for the Euro area economies. Bekaert et al. (2000) provide evidence that substantiates their results, even accounting for structural breaks. The same results also hold from Hardouvelis et al. (2006), who report a lower 
cost of capital reflecting higher capital market integration in Euroland.

Aggarwal and Kyaw (2005) investigate the convergence trends of three North American Free Trade Agreement (NAFTA) economies and find cointegration between equity prices only over the period after the formation of NAFTA, while Darrat and Zhong (2005) argue that the NAFTA formation contributed to a greater speed of convergence among NAFTA members. Ciner (2006) identifies a high degree of convergence among North American equity markets, especially during the 1990s, on the basis of the boom in information technology stocks as well as by the dismantling of trade barriers. Chukwuogor-Ndu (2007) and Chukwuogor-Ndu and Kasibhatla (2007) also confirm convergence patterns for North American equity markets. Finally, Canarella, Miller, and Pollard (2009), using daily data from 1992 to 2007, examine (i) the long-run relationship between the three NAFTA equity markets, using cointegration techniques, (ii) the dynamic relationships between the three markets, using impulse-response analysis, and (iii) the volatility transmission process between the three markets, using a multivariate generalized autoregressive conditional heteroskedasticity model. They do not find evidence of cointegration between the three NAFTA stock markets nor any tendency toward such a long-run trend relationship. But, they do find significant volatility transmission between the NAFTA stock markets.

To determine convergence in global equity markets, researchers use a variety of approaches. One method uses asset-pricing models to determine whether equity returns reflect global rather than local risk factors (Bekaert and Harvey, 1995; Karolyi and Stulz, 2002). Another method highlights the importance of country-specific effects in convergence among equity markets (Baca et al., 2000; Cavaglia et al., 2000). Adjaoute and Danthine (2000) argue that enhanced European Union (EU) diversification during the 1990s implies a stronger pattern 
of integration. Moreover, EU factors play a dominant role relative to country-specific factors. Nevertheless, they also argue that strong differences in taxation, reporting, and accounting standards exist in EU capital markets. The introduction of the euro does not eliminate home bias.

Using equity return correlation analysis, Fratzscher (2002) finds a stronger correlation of stock returns, which reflects greater integration among equity markets, especially in Europe, due to the elimination of currency risk as well as from the convergence of monetary policies. Cappiello et al. (2009) and Rahman and Khan (2009) confirm these findings, especially for European equity markets that share common characteristics, such as strong liquidity and market capitalization. Yang et al. (2003b) consider linkages across equity markets through cointegration. They employ $11 \mathrm{EU}$ equity markets and find long-run linkages among them, especially following the formation of the European Monetary Union (EMU).

Another group of studies uses $\sigma$-convergence analysis. In particular, Babetskii et al. (2007) find evidence of substantial stock-market integration with respect to new members of the EU. By contrast, Sy (2006) uses the same methodology and reaches the opposite conclusion for the West African Economic and Monetary Union economies. Following Corhay et al. (1993) and Engsted and Lund (1997), Rangvid (2001) utilizes recursive common stochastic trend analysis to find convergence for three European equity markets. On the other hand, Gleria et al. (2004) employ the truncated Levy flight approach to find a relatively slow convergence among equity markets. Finally, the home-bias-effect method (i.e., investors invest primarily in their own country) suggests that a reduced home bias effect implies a greater degree of integration among international equity markets. Adam et al. (2002) and Lane and Milesi-Ferretti (2008) find that the relative size of the local equity market remained stable over time, while the equity home bias diminished, especially in Europe. 
A different strand of research investigates convergence patterns in capital markets, focusing on the relative importance of country versus industry effects in driving stock-market returns. Fraser et al. (1994) use disaggregated data for various industrial sectors for Europe and the US along with a time-varying methodology. They find that much more convergence among European capital markets can yet occur. Griffin and Karolyi (1998) use 66 industry indices from 25 countries and confirm the dominance of country effects in portfolio selection. By contrast, Baca et al. (2000), Cavaglia et al. (2000), Isakov and Sonney (2002), and Adjaoute and Danthine (2003) argue in favor of the increasing importance of industry factors over the last twenty years. Brooks and Del Negro (2004) provide an opposing view and report results that support country effects for all industrial sectors, excluding the technology, media, and telecommunication sector in which industry effects work better in determining portfolio diversification issues. Ferreira and Gama (2005) report that industry diversification becomes more effective in risk reduction than geographical diversification over the last twenty years. They attribute these findings to rising industry volatility vis-à-vis country volatility as well as a global trend in the correlations among local industries. Ferreira and Ferreira (2006) use a number of industries in the Euro area. They argue that international financial management requires the identification of country and industry effects in explaining portfolio returns. Their empirical findings show that country effects still dominate the determination of stock market returns. Over the last ten years, however, industry effects gain increasing importance, implying that although international portfolio diversification remains an effective tool for risk reduction vis-à-vis industry diversification its relative importance keeps decreasing over time.

Finally, several studies examine stock market volatility, since such volatility can impair not only the smooth functioning of such markets, but also the performance of the entire economy 
(Levine and Zervos, 1996; Bekaert and Harvey, 1997; Poterba, 2000; Arestis et al., 2001). Thus, higher (lower) volatility indicates higher (lower) risks to equity investments and, thus, the shift of funds away from (toward) the stock market to safer investments, leading to lower (higher) stock prices. Ferreira and Gama (2005) provide strong support to the argument that volatility signals endogenous changes in capital markets. More specifically, they argue that changes in volatility reflect changes in trading volumes or practices within industries (industry effects) rather than within geographical regions and, thus, do not reflect changes in macroeconomic fundamentals and/or macroeconomic policies.

\section{Econometric Methodology}

Phillips and Sul (2007) propose a new econometric approach to test for convergence and the identification of convergence clubs. Their method uses a nonlinear time-varying factor model and provides the framework for modeling the transitional dynamics as well as long-run behavior. More specifically, consider a set of observable series $y_{i t}$ of country i such that:

$$
y_{i t}=\delta_{i t} \mu_{t} \text {, }
$$

where $\mu_{t}$ is a single common component and $\delta_{i t}$ is a time varying idiosyncratic element which captures the deviation of country i from the common path defined by $\mu_{t}$. Within this framework, all $N$ economies (either the entire sample or the cluster) will converge, at some point in the future, to the steady state if $\lim _{k \rightarrow \infty} \delta_{i t+k}=\delta$ for all $i=1,2, \ldots, N$, irrespective of whether countries are near the steady state or in transition. This is important, since the paths to the steady state (or states) across countries can differ significantly. Since we cannot estimate $\delta_{i t}$ directly from equation (1) due to over-parameterization, Phillips and Sul $(2006,2007)$ eliminate the common component $\mu_{t}$ through rescaling by the panel average as follows: 


$$
h_{i t}=\frac{y_{i t}}{\frac{1}{N} \sum_{i=1}^{N} y_{i t}}=\frac{\delta_{i t}}{\frac{1}{N} \sum_{i=1}^{N} \delta_{i t}} .
$$

The relative measure $h_{i t}$ captures the transition path with respect to the panel average. A formal econometric test of convergence and an empirical algorithm to define club convergence requires that we assume the following semi-parametric form for the time-varying coefficients $\delta_{i t}$ :

$$
\delta_{i t}=\delta_{i}+\sigma_{i t} \xi_{i t}
$$

where $\sigma_{i t}=\frac{\sigma_{i}}{L(t) t^{\alpha}}, \sigma_{i}>0, t \geq 0$, and $\xi_{i t}$ is weakly dependent over $t$, but iid(0,1) over $i$. The function $L(t)$, which we set equal to logt, varies slowly, increasing and divergent at infinity. Under this specification for $\delta_{i t}$, the null hypothesis of convergence for all $i$ takes the form: $H_{0}: \delta_{i}=\delta, \quad \alpha \geq 0$ while the alternative hypothesis of non-convergence for some $i$ takes the form: $H_{A}: \delta_{i} \neq \delta$ or $\alpha<0$. Phillips and Sul (2007) show that we can test the null of convergence in the following regression: ${ }^{1}$

$$
\log \left(\frac{H_{1}}{H_{t}}\right)-2 \log L(t)=\hat{c}+\hat{b} \log t+\hat{u}_{t}
$$

for $t=[r T],[r T]+1, \ldots, T$, and $r>0 .^{2}$ In this regression, $H_{t}=\frac{1}{N} \sum_{i=1}^{N}\left(h_{i t}-1\right)^{2}$ and $\hat{b}=2 \hat{\alpha}$, where $h_{i t}$ is defined in equation (2) and $\hat{\alpha}$ is the least squares estimate of $\alpha$. Under the null hypothesis of convergence, the dependent variable diverges whether $\alpha>0$, or $\alpha=0$. In this case, we can test the convergence hypothesis with a t-test of the inequality, $\alpha \geq 0$. The t-test statistic follows the standard normal distribution asymptotically and is constructed using a

\footnotetext{
${ }^{1}$ The analytic proof under the convergence hypothesis for this regression equation appears in Appendix B of Phillips and Sul (2007).

${ }^{2}$ Following Phillips and Sul (2007), we choose r values in the interval [0.2, 0.3].
} 
heteroskedasticity and autocorrelation consistent standard error. Phillips and Sul (2007) call the one-sided $t$-test, which is based on $t_{\hat{b}}$, the $\log t$ test due to the presence of the $\log (\mathrm{t})$ regressor in equation (4). ${ }^{3}$

The possible existence of multiple equilibria is an important issue in the empirical convergence literature. In this case, rejecting the null hypothesis that all countries in the sample converge does not imply the absence of different convergence clubs in the panel. In this study, we implement the club convergence and clustering procedure proposed by Phillips and Sul (2007) as follows. First, order the $N$ countries according to the value of the final times series. Second, form all possible core groups $C_{k}$ by selecting the first $k$ highest countries, with $k=2,3, \ldots, N$. Third, test for convergence using the $\log t_{k}$ test within each subgroup of size $k$. Fourth, define the core group $C^{*}$ of size $k^{*}$ as the group for which the maximum $\log t_{k^{*}}$ statistic occurs, given, of course, that all $\log t_{k}$ statistics over which we maximize supports the convergence hypothesis. Fifth, equation (3) finds that all the countries, according to the logt test, converge to the same steady state with the core group $C^{*}$. Sixth, this identifies the first convergence club in the panel. Seventh, for the remaining countries (if any), repeat the procedure to determine the next convergence club, if more exist. Finally, terminate the process when the remaining economies fail to converge.

Finally, we test the robustness of the initial convergence test on the entire sample of countries as follows. In those cases where we cannot reject the null hypothesis of convergence for all countries, we proceed and implement the club convergence test. Typically, the club convergence test supports the initial test for overall convergence of all countries. Exceptions do

\footnotetext{
${ }^{3}$ The logt test exhibits favorable asymptotic and finite sample properties.
} 
occur. See discussions below.

\section{Empirical Analysis}

\subsection{Data}

Our sample consists of markets characterized by diversity in terms of the size of capitalization, liquidity, breath, and depth. In particular, we investigate the following 42 countries: Argentina (ARG), Austria (AUT), Belgium (BEL), Brazil (BRA), Canada (CAN), Chile (CHL), China (CHN), Colombia (COL), Cyprus (CYP), the Czech Republic (CZE), Denmark (DNK), Finland (FIN), France (FRA), Germany (DEU), Greece (GRC), Hungary (HUN), India (IND), Indonesia (IDN), Ireland (IRL), Israel (ISR), Italy (ITA), Japan (JPN), Korea (KOR), Luxembourg (LUX), Malaysia (MYS), Mexico (MEX), the Netherlands (NLD), Norway (NOR), Pakistan (PAK), Peru (PER), the Philippines (PHL), Poland (POL), Portugal (PRT), Singapore (SGP), South Africa (ZAF), Spain (ESP), Sweden (SWE), Switzerland (CHE), Thailand (THA), Turkey (TUR), the United Kingdom (GBR), and the United States (USA). Datastream provided the monthly and daily data on stock market indices. The data span the period January 1980 to December 2008. Although data beyond 2008 exist, we stop at 2008 to leave out the break out of the recent financial crisis, which deserves a special treatment. In addition, we obtained data for a great variety of industrial sectors. In particular, we separate the industries under investigation into two types: general categories and specific sectors. The general categories include basic materials (41), consumer goods (38), consumer services (36), financials (36), healthcare (27), industrial (39), oil-gas (27), technology (19), telecommunications (23), and utilities (24), while the specific sectors include aero-defense (7), construction materials (35), electronics (18), engineering (23), general industries (26), services (16), and transportation (26). ${ }^{4}$

\footnotetext{
${ }^{4}$ The number of countries included in each category appears in parentheses.
} 
We construct monthly realized volatility by summing squared daily returns over the corresponding months. Andersen et al. (2001) and Barndorff-Nielsen and Shephard (2001, 2002) demonstrate that realized volatility constructed from high frequency data provide an unbiased and efficient estimator of returns volatility. In our case, high frequency data is not available; therefore, we compute realized volatility from daily returns. In addition, we also collect consumer price indexes (CPIs) from each country from Datastream to deflate nominal stock price indexes. The real index matters for capital gains, especially in a long-term analysis.

For all data, we use the Hodrick-Prescott filter procedure to extract the trend component from the natural logarithms of the series under examination. We adopt this procedure since convergence is a long-run (or trend) concept. That is, using the actual series potentially contaminates our results, since financial aggregates contain a substantial amount of short-run variation. We also use the time-varying parameter framework by Stock and Watson (1998) to decompose the trend component. Since the results do not change much, we do not report them but they are available upon request. Since the Phillips-Sul convergence methodology depends on the relative transition parameters, all panel cross-section means must be positive, which in our case holds, since the means of our variables are positive. Finally, we used the GAUSS software for the empirical analysis.

\subsection{Convergence of the Stock Market Index and Its Volatility}

The top half of Table 1 reports the results of the panel convergence methodology for real stock market indices, while the bottom half reports the results for their volatility. The first column reports the result of testing full convergence, (i.e., convergence among all sample countries), while columns 2 to 4 display the results of the club clustering procedure.

We reject the null hypothesis of full convergence for the real stock market indices. The 
results of the club clustering algorithm for the stock market indices show that over the period under investigation two convergent clubs exist. More specifically, the first club contains 33 equity markets while the second club includes 8 equity markets - Argentina, Italy, Japan, Malaysia, Pakistan, Philippines, Singapore, and the UK. Finally, the equity market of Thailand follows an independent path not convergent with either clubs 1 or 2 . The lack of full convergence of international equity markets, and, more importantly, the formation of two convergent clubs, calls for the investigation of alternative factors that may contribute to such divergent patterns for real equity prices. Accordingly, we investigate whether country or industry effects lead to such behavior.

Apergis et al. (2011) find two convergence clubs for their sample of developed countries. Our sample of developed countries includes Germany and Spain, which they exclude. They include Australia and New Zealand, which do not appear in our sample. They find Japan as a non-convergence country. We find Japan included with other Southeast Asian countries Malaysia, Singapore and Thailand - as well as Italy and the U.K.

Table 1 also shows that we cannot reject the null hypothesis of full convergence for stock market volatility. In other words, the results of the club convergence algorithm indicate the presence of a single convergent club.

\subsection{Convergence of the General Industries Indices and Their Volatilities}

This sub-section examines whether the non-convergence patterns of the stock market indices signal any potential industry effects. We begin with the presentation of general industry categories. Table 2 reports the convergence results for basic materials in terms of both the stock market indices and their volatilities. The top of Table 2 shows that we reject the null hypothesis of full convergence for the basic materials real stock indices. The results of the club convergence 
algorithm, however, indicate the presence of only one club with all countries included, except Malaysia, which belongs in the non-converging club. The bottom of Table 2 shows that we cannot reject the null hypothesis of full convergence for basic materials stock market indices volatility. In other words, the results of the club convergence algorithm indicate the presence of a single convergent club.

Tables 3 reports the results for the consumer goods stock market index, finding that three convergence clubs exist for consumer goods. In other words, there exists more divergence in stock market indices for consumer goods. This implies more room for diversifying an investor's portfolio across countries in consumer goods. Table 3 also reports different findings for club convergence of the consumer goods volatility measures, finding 5 convergence clubs for consumer goods and indicating a high degree of divergence. By contrast, with respect to the consumer services index, the results in Table 4 display a different picture. In terms of the index level, the analysis finds 4 convergence clubs, while for volatility, the analysis fails to reject the null hypothesis of full convergence for the countries participating in the sample.

Table 5 through 11 report the findings for the rest of the generalized indices - financial, healthcare, industrial, oil-gas, technology, telecommunications, and utilities indices. These findings generally fall within the limits of the basic materials and the consumer goods and services indices. Applying the convergence club algorithm to the financial, healthcare, industrial, oil-gas, technology, telecommunications, and utilities indices generates 4, 2, 4, 4, 3, 2, and 2 convergence clubs, respectively, sometimes with and sometimes without a non-converging country club. Also, when we examine the convergence clubs for the volatilities of the stock market indices for the financial, healthcare, industrial, oil-gas, technology, telecommunications, and utilities indices, we find $1,1,1,1,3,4$, and 1 convergence clubs, respectively. With two 
exceptions, the volatilities form fewer convergence clubs than the stock market indices themselves. The exceptions, the technology and telecommunications indices, exhibited 3 and 4 clubs, respectively, for their stock market indices. Moreover, in these two cases, the countries in the level clubs do not show a similar pattern with the volatility clubs.

All in all, the preceding empirical analysis suggests that considerable heterogeneity exists in the structure of our country sample and in terms of industry classification. This heterogeneity suggests that differences will exist in how economic shocks affect the course of capital markets in each economy. In terms of volatility, however, a different picture emerges. Ferreira and Gama (2005) support the argument that volatility signals endogenous changes in capital markets. More specifically, they argue that changes in volatility reflect changes in trading volumes or practices within industries rather than within geographical regions and, thus, do not reflect changes in macroeconomic fundamentals, in macroeconomic policies, or in the institutional and political environment of the stock markets. According to our results, several sectors (i.e., basic materials, finance, industrial, oil-gas, and utilities), exhibit a single convergence club in terms of the volatility of their stock prices. Health care also finds one club, but one country, Portugal, does not belong to this club and does not converge.

\subsection{Convergence of the Specific Industries Indices and Their Volatilities}

Tables 12 through 18 report the convergence results for the aero-defense, construction materials, electronics, engineering, general industries, services, and transport indices and their volatilities. As before, the top and bottom of the tables reports the convergence results for the stock market indices and their volatilities, respectively. The convergence club algorithm identifies 2, 3, 4, 3, 3, 4, and 2 clubs for the real stock market indices of the aero-defense, construction materials, electronics, engineering, general industries, services, and transport industries, respectively. In 
terms of volatility, the algorithm displays the presence of a single convergence club (in which all countries belong) in indices with the exception in the services and transport sectors in which the analysis identifies 4 and 2 clubs, respectively. Once again, we generally find that fewer volatility clubs exist when compared to the levels of stock market index clubs.

\section{Conclusions}

This study examines the convergence of international equity markets and their volatilities. It also departs from the standard approach in the finance literature in testing for convergence and borrows from the literature on the convergence of macroeconomic variables. That is, we implement the methodology of Phillips and Sul (2007), which uses a non-linear time-varying factor model with common and idiosyncratic components and which allows for technical progress heterogeneity across countries.

The empirical findings suggested that international equity markets do not form a homogeneous convergence club. Since a country's equity market aggregates the markets of individual industries, these findings may reflect specific endogenous characteristics within industries that prevent convergence at the industry level rather than country-specific factors. For example, country-specific factors may relate to differences in the level of development or in macroeconomic policies. On the other hand, industry-specific factors may reflect differences in human capital availability or diffusion of technical advances across international borders.

As a result, we repeat the empirical analysis across industries. The new empirical findings display even less convergence at the industry level, as characterized by more convergence clubs. That is, the heterogeneity across industries increases relative to that for the stock market indices themselves. Therefore, industry-related effects tend to dominate country-related effects, indicating that geography seems less important for portfolio diversification. The results are 
consistent with those reported by Campa and Fernandes (2006), who find that the driving force for the rise in global industry shocks is the faster transmission of shocks across industries and not across countries when it comes down to explaining financial aggregates.

In sum, our findings on the country and industry effects of convergence provide support for a diminishing country effect. That is, the presence of multiple convergence clubs within industries suggests that the industries do not converge toward a uniform structure. As such, room may still exist for significant benefits from diversifying across countries within a given industry. Conversely, the relatively large cross-country convergence club for the overall stock markets suggests less room for significant benefits from diversifying across geographical stock markets.

The convergence of volatilities tells a different story. We find one convergence club for the volatilities of the stock market indices. In addition, although we do find evidence of convergence clubs for industry level volatilities, fewer such clubs generally exist as compared to the clubs for the stock market indices from which the volatilities derive. Stated differently, we find more evidence of convergence in the second moment of the stock market indices than in the first moment. Such convergence may provide a precursor to convergence in the stock market indices themselves. That is, investors choose those markets with the higher expected return and tend to provide the impetus for convergence of the stock market indices. If such convergence continues, then the diversification advantages of portfolio investment across countries will prove less attractive.

These results seem crucial for portfolio managers and policy makers. That is, the convergence of stock market indices and their volatilities magnifies the importance of spillover effects between capital markets, since shocks emerging from a specific country or industry in an economy can quickly spread to other industries or countries. Our findings also seem important 
for regulators. More specifically, improved convergence of stock market indices and volatilities may impair the efficacy of the regulatory framework within a country or industry. Therefore, a new capital market architecture and regulatory framework may become necessary.

Finally, future empirical work can extend this work to a broader examination of the role of other factors, such as capital controls, liquidity restrictions, and regulation issues across industries and across countries in explaining stock market convergence patterns. 


\section{References}

Adam, K., Jappelli, T., Menichini, A., Padula, M., and Pagano, M., 2002. Analyze, Compare and Apply Alternative Indicators and Monitoring Methodologies to Measure the Evolution of Capital Market Integration in the European Union. Report to the European Commission.

Adjaoute, K., and Danthine, J. P., 2004. Equity Returns and Integration: Is Europe Changing? FAME Research Paper, No. 117.

Adjaoute, K., and Danthine, J. P., 2003. European Financial Integration and Equity Returns: A Theory-Based Assessment. FAME Research Paper Series, International Center for Financial Asset Management and Engineering.

Adjaoute, K., and Danthine, J. P., 2000. EMU and Portfolio Diversification Opportunities. Center for Economic Policy Research, Discussion Paper, No. 2962.

Adler, M., and Dumas, B., 1983. International Portfolio Choice and Corporation Finance: A Synthesis. Journal of Finance 38, 925-984.

Aggarval, R., and Kyaw, N. A., 2005. Equity Market Integration in NAFTA Region: Evidence from Unit Root and Cointegration Tests. International Review of Financial Analysis 14, 393-406.

Andersen, T. G., Bollerslev, T., Diebold, F. X., and Ebens, H., 2001. The Distribution of Realized Stock Return Volatility. Journal of Financial Economics 61, 43-76.

Apergis, N., Christou, C. and Payne, J. (2011) 'Political and Institutional Factors in the Convergence of International Equity Markets: Evidence from the Club Convergence and Clustering Procedure', Atlantic Economic Journal 39, 7-18.

Arestis, P., Demetriades, P. O., and Luintel, K. B., 2001. Financial Development and Economic Growth: The Role of Stock Markets. Journal of Money, Credit and Banking 33, 16-41.

Arouri, M. E. H., 2004. The Impact of Increasing Stock Market Integration on Expected Gains from International Portfolio Diversification: Evidence from a Multivariate Approach with Time Varying Risk. Economics Bulletin 6, 1-13.

Ayso, J., and Blanco, R., 2000. Has Financial Market Integration Increased during the Nineties? Journal of International Financial Markets, Institutions and Money 11, 265-287.

Azariadis, C., and Drazen, A., 1990. Threshold Externalities in Economic Development. Quarterly Journal of Economics 105, 501-526.

Babetskii, I., Komarek, L., and Komarkova, Z., 2007. Financial Integration of Stock Markets among New EU Member States and the Euro Area. Czech Journal of Economics and Finance 57, 341-362. 
Baca, S. P., Garbe, B. L., and Weiss, R. A., 2000. The Rise of Sector Effects in Major Equity Markets. Financial Analyst Journal 56, 34-40.

Baele, L., Ferrando, A., Hordhal, P., Krylova, E., and Monnet, C., 2004. Measuring Financial Integration in the Euro Area. Oxford Review of Economics 20, 509-530.

Barndorff-Nielsen, O. E., and Shephard, N., 2002. Econometric Analysis of Realized Volatility and its USE in Estimating Stochastic Volatility Models. Journal of the Royal Statistical Society Series B 64, Part 2, 253-280.

Barndorff-Nielsen, O. E., and Shephard, N., 2001. Non-Gaussian Ornstein-Uhlenbeck-Based Models and Some of Their Use in Financial Economics. Journal of the Royal Statistical Society Series B 63, 167-241.

Bekaert, G., Hodrick, R., and Zhang, X., 2009. International Stock Return Co-movements. Journal of Finance 54, 2591-2626.

Bekaert, G., Campbell, R. H., and Lumsdaine, R. L., 2000. Dating the Integration of World Equity Markets. Journal of Financial Economics 65, 203-247.

Bekaert, G., and Harvey, C. R., 1997. Emerging Equity Market Volatility. Journal of Financial Economics 43, 29-77.

Bekaert, G., and Harvey, C. R., 1995. Time-Varying World Market Integration. Journal of Finance, 403-444.

Bliss, C., 2000. Galton's Fallacy and Economic Convergence: A Reply to Cannon and Duck. Oxford Economic Papers 52, 420-422.

Bliss, C., 1999. Galton’s Fallacy and Economic Convergence. Oxford Economic Papers 51, 414.

Brooks, R., and Del Negro, M., 2004. The Rise in Comovement Across national Stock Markets: Market Integration or IT Bubble? Journal of Empirical Finance 11, 659-680.

Campa, J. M., and Fernandes, N., 2006. Sources of Gains from International Portfolio Diversification. Journal of Empirical Finance 13, 417-443.

Canarella, G., Miller, S. M., and Pollard, S. K., 2010. NAFTA Stock Markets: Dynamic Return and Volatility Linkages. Nova Science Publishers, Inc.

Caporale, G. M., Erdogan, B., and Kuzin, V., 2009. Testing for Convergence in Stock markets: A Non-Linear Factor Approach. Discussion Paper No. 932, Deutsches Institut fur Wirtschaftsforschung, Berlin. 
Cappiello, L., Kadareja, A., and Manganelli, S., 2009. The Impact of the Euro on Equity Markets. Journal of Financial and Quantitative Analysis 45, 473-502.

Carrieri, F., Errunza, V., and Sarkissian, S., 2008. The Dynamics of Geographic Versus Sectional Diversification: Is There a Link to the Real Economy? Working paper, McGill University.

Cavaglia, S., Brightman, C., and Aked, M., 2000. The Increasing Importance of Industry Factors. Financial Analysts Journal, 31-39.

Cerny, A., 2004. Stock Market Integration and the Speed of Information Transmission. CERGEEI Working Paper Series, No. 242.

Christoffersen, P., Errunza, V., Jacobs, K., and Jin, X., 2010. Is the Potential for International Diversification Disappearing? Available at SSRN: http://ssrn.com/abstarct $=1573345$ or http://dx.doi.org/10.2139/ssrn.1573345.

Chukwuogor-Ndu, C., 2007. Stock Market Returns and Volatilities: A Global Comparison. Global Journal of Finance and Banking Issues 1, 1-17.

Chukwuogor-Ndu, C., and Kasibhatla, K., 2007. Post NAFTA Integration of North American Stock Markets: Implications for Financial Decision Making. North American Journal of Finance and Banking Research 1, 37-53.

Ciner, C., 2006. A Further Look at Linkages between NAFTA Equity Markets. The Quarterly Review of Economics and Finance 46, 338-352.

Corhay, A. A., Rad, T., and Urbain, J., 1993. Common Stochastic Trends in European Stock Markets. Economic Letters 42, 385-390.

Darrat, A. F., and Zhong, M., 2005. Equity Market Linkages and Multinational Trade Accords: The Case of NAFTA. Journal of International Money and Finance 24, 793-817.

Dickinson, D. G., 2000. Stock Market Integration and Macroeconomic Fundamentals: An Empirical Analysis, 1980-95. Applied Financial Economics 10, 261-276.

Durlauf, S., and Johnson, P., 1995. Multiple Regimes and Cross-Country Growth Behavior. Journal of Applied Econometrics 10, 365-384

Egert, B., and Kočenda, E., 2007. Interdependence between Eastern and Western European Stock Markets: Evidence from Intraday Data. Economic Systems 31, 184-203.

Eiling, E., and Gerard, B., 2007. Dispersion, Equity Return Correlations and Market Integration. Working Paper, University of Toronto. 
Engsted, T., and Lund, J., 1997. Common Stochastic Trends in International Stock Prices and Dividends: An Example of Testing Overidentifying Restrictions on Multiple Cointegration Vectors. Applied Financial Economics 7, 659-665.

Errunza, V., Hogan, K., and Hung, M-W., 1999. Can the Gains from International Diversification Be Achieved Without Trading Abroad? Journal of Finance 54, 20752107.

Eun, C. S. and Lee, J., 2010. Mean-Variance Convergence around the World. Journal of Banking and Finance 34, 856-870.

Ferreira, M. A., 2004. The Importance of Industry and Country Effects in the EMU Equity Markets. Available at SSRN: http://ssrn.com/abstract=392640.

Ferreira, M. A., and Ferreira, M. A., 2006. The Importance of Industry and Country Effects in the EMU Equity Markets. European Financial Management 12, 341-373.

Ferreira, M. A., and Gama, P. M., 2005. Have World, Country and Industry Risk Changed Over Time? An Investigation of the Developed Stock Markets Volatility. Journal of Financial and Quantitative Analysis 40, 195-222.

Fraser, P., Helliar, C. V., and Power, D. M., 1994. An Empirical Investigation of Convergence among European Equity Markets. Applied Financial Economics 4, 149-157.

Fratzscher, M., 2002. Financial Market Integration in Europe: On the Effects of EMU on stock Markets. International Journal of Finance and Economics 7, 165-193.

Fritsche, U., and Kuzin, V., 2008. Analyzing Convergence in Europe Using a Nonlinear Single Factor Model. Macroeconomics and Finance Series, No. 200802, Hamburg University, Department Wirtschaft und Politik.

Gleria, I., Figueiredo, A., Matsushita, R., Rathie, P., and Da Silva S., 2004. Exponentially Damped Levy Flights, Multiscaling and Slow Convergence in Stockmarkets. Physica A 342, 200-206.

Goetzmann, W., Li, L., and Rouwenhorst, G., 2001. Long-Term Global Market Correlations. NBER Working Paper, No. 8612.

Griffin, J. M., and Karolyi, G. A., 1998. Another Look at the Role of the Industrial Structure of Markets for International Diversification Strategies. Journal of Financial Economics 50, 351-373.

Grubel, H., 1968. Internationally Diversified Portfolios: Welfare Gains and Capital Flows. American Economic Review 58, 1299-1314. 
Hanousek, J., and Filler, R., 2000. The Relationship between Economic Factors and Equity Markets in Central Europe. Economics of Transition 8, 623-638.

Hardouvelis, G., Malliaropoulos, D., and Priestley, R., 2006. EMU and European Stock Market Integration. Journal of Business 79, 365-392.

Hartmann, P., Maddaloni, A., and Manganelli, S., 2003. The Euro Area Financial System: Structure, Integration and Policy Initiatives. Oxford Review of Economic Policy 19, 180213.

Isakov, D., and Sonney, S., 2002. Are Practitioners Right? On the Relative Importance of International Portfolios in International Stock Returns. FAME Research Paper.

Jayasuriya, S., and Shambora, W., 2008. The World is Shrinking: Evidence from Stock Market Convergence. Economics Bulletin 7, 1-12.

Karolyi, G. A., and Stulz, R. M., 2002. Are Financial Assets Locally or Globally? NBER Working Paper Series, No. W8994.

King, M., Sentana, E., and Wadhwani, S., 1994. Volatility and Links between National Stock Markets. Econometrica 62, 901-933.

Lane, P., and Milesi-Ferretti, G. M., 2008. International Investment Patterns. Review of Economics and Statistics 90, 538-549.

Leachman, L. L., and Francis, B., 1995. Long-Run Relations Among the G-5 and G-7 Equity Markets: Evidence on the Plaza and Louvre Accords. Journal of Macroeconomics 17, 551-577.

Levine, R., and Zervos, S., 1996. Stock Market Development and Long-Run Growth. World Bank Economic Review 10, 323-339.

Levy, H., and Sarnat, M., 1970. International Diversification of Investment Portfolios. American Economic Review 60, 668-675.

Longin, F., and Solnik, B., 1995. Is the Correlation in International Equity Returns Constant: 1960-1990? Journal of International Money and Finance 14, 3-26.

Miller, S. M., and Upadhyay, M. P., 2002. Total factor productivity and the convergence hypothesis. Journal of Macroeconomics 24, 267-286.

Phillips, P. C. B., and Sul, D., 2007. Transition Modeling and Econometric Convergence Tests. Econometrica 75, 1771-1855.

Phillips, P. C. B., and Sul, D., 2006. Economic Transition and Growth. Mimeo, University of Auckland. 
Piesse, J., and Hearn, B., 2002. Equity Market Integration versus Segmentation in Three Dominant Markets of the Southern African Customs Union: Cointegration and Causality Tests. Applied Economics 14, 1711-1722.

Portes, R., and Rey, H., 2005. The Determinants of Cross-Border Equity Flows. Journal of International Economics 65, 269-296.

Poterba, J. M., 2000. Stock Market Wealth and Consumption. Journal of Economic Perspectives 14, 99-118.

Poterba, J. M., and Summers, L. H., 1998. Mean Reversion in Stock Prices. Journal of Financial Economics 22, 27-59.

Rahman, M., and Khan, M. M., 2009. The Euro and Convergence Among Stock Markets of Germany, France and Italy. Global Economy Journal 9, 1-13.

Rangvid, J., 2001. Increasing Convergence among European Stock Markets? A Recursive Common Stochastic Trends Analysis. Economics Letters 71, 383-389.

Solnik, B., 1974. Why Not Diversify Internationally Rather than Domestically? Financial Analysts Journal 30, 48-54.

Stock, H. J. and Watson, M. W., (1998). Median Unbiased Estimation of Coefficient Variance in a Time-Varying Parameter Model. Journal of the American Statistical Association 93, 349-358.

Sy, A. N. R., 2006. Financial Integration in the West African Economic and Monetary Union. International Monetary Fund, IMF Working Paper WP/06/214.

Yang, J., Kolari, J. W., and Min, I., 2003a. Stock Market Integration and Financial Crises: The Case of Asia. Applied Financial Economics 13, 477-486.

Yang, J., Min, I., and Li, Q., 2003b. European Stock Market Integration: Does EMU Matter? Journal of Business, Finance and Accounting 30, 1253-1276. 
Table 1: Club Convergence: Stock Market

\begin{tabular}{|c|c|c|c|c|}
\hline \multicolumn{5}{|l|}{ Level } \\
\hline Club Type & $\begin{array}{l}\text { Only One } \\
\text { Club }\end{array}$ & First Convergence Club & $\begin{array}{c}\text { Second } \\
\text { Convergence Club }\end{array}$ & $\begin{array}{l}\text { Not Converging } \\
\text { Countries }\end{array}$ \\
\hline $\begin{array}{l}\text { Countries } \\
\text { Included }\end{array}$ & $\begin{array}{c}\text { ALL } \\
\text { COUNTRIES }\end{array}$ & $\begin{array}{l}\text { AUT, BEL, BRA, CAN, CHL, } \\
\text { CHN, COL, CYP, CZE, DNK, FIN, } \\
\text { FRA, DEU, GRC, HUN, IND, IDN, } \\
\text { IRL, ISR, KOR, LUX, MEX, NLD, } \\
\text { NOR, PER, POL, PRT, ZAF, ESP, } \\
\text { SWE, CHE, TUR, US }\end{array}$ & $\begin{array}{l}\text { ARG, ITA, JPN, } \\
\text { MYS, PAK, PHL, } \\
\text { SGP, UK }\end{array}$ & THA \\
\hline logt Test & -5.094 & 8.963 & 15.834 & \\
\hline \multicolumn{5}{|l|}{ Volatility } \\
\hline Club Type & $\begin{array}{l}\text { Only One } \\
\text { Club }\end{array}$ & First Convergence Club & $\begin{array}{c}\text { Second } \\
\text { Convergence Club }\end{array}$ & $\begin{array}{c}\text { Not Converging } \\
\text { Countries }\end{array}$ \\
\hline $\begin{array}{l}\text { Countries } \\
\text { Included }\end{array}$ & $\begin{array}{c}\text { ALL } \\
\text { COUNTRIES }\end{array}$ & & & \\
\hline logt Test & 16.772 & & & \\
\hline $\begin{array}{l}\text { Note: } \\
\text { The } \\
\text { (AL } \\
\text { Cyp } \\
\text { (DE } \\
\text { (IT } \\
\text { (NL } \\
\text { (PR } \\
\text { (TH }\end{array}$ & \multicolumn{4}{|c|}{$\begin{array}{l}\text { The abbreviations for the } 42 \text { countries in the whole sample are as follows: Argentina (ARG), Austria } \\
\text { (AUT), Belgium (BEL), Brazil (BRA), Canada (CAN), Chile (CHL), China (CHN), Colombia (COL), } \\
\text { Cyprus (CYP), the Czech Republic (CZE), Denmark (DNK), Finland (FIN), France (FRA), Germany } \\
\text { (DEU), Greece (GRC), Hungary (HUN), India (IND), Indonesia (IDN), Ireland (IRL), Israel (ISR), Italy } \\
\text { (ITA), Japan (JPN), Korea (KOR), Luxembourg (LUX), Malaysia (MYS), Mexico (MEX), the Netherlands } \\
\text { (NLD), Norway (NOR), Pakistan (PAK), Peru (PER), the Philippines (PHL), Poland (POL), Portugal } \\
\text { (PRT), Singapore (SGP), South Africa (ZAF), Spain (ESP), Sweden (SWE), Switzerland (CHE), Thailand } \\
\text { (THA), Turkey (TUR), the United Kingdom (GBR), and the United States (USA). }\end{array}$} \\
\hline
\end{tabular}

Table 2: $\quad$ Club Convergence: Basic Materials

\begin{tabular}{|c|c|c|c|}
\hline \multicolumn{4}{|l|}{ Level } \\
\hline Club Type & Only One Club & First Convergence Club & $\begin{array}{l}\text { Not Converging } \\
\text { Countries }\end{array}$ \\
\hline $\begin{array}{l}\text { Countries } \\
\text { Included }\end{array}$ & $\begin{array}{c}\text { ALL } \\
\text { COUNTRIES }\end{array}$ & $\begin{array}{l}\text { ARG, AUT, BEL, BRA, CAN, CHL, CHN, COL, } \\
\text { CZE, DNK, FIN, FRA, DEU, GRC, HUN, IND, } \\
\text { IDN, IRL, ISR, ITA, JPN, KOR, LUX, MEX, NLD, } \\
\text { NOR, PAK, PER, PHL, POL, PRT, SGP, ZAF, } \\
\text { ESP, SWE, CHE, THA, TUR, UK, US }\end{array}$ & MYS \\
\hline logt Test & -4.845 & 2.120 & \\
\hline \multicolumn{4}{|l|}{ Volatility } \\
\hline Club Type & Only One Club & First Convergence Club & $\begin{array}{c}\text { Not Converging } \\
\text { Countries }\end{array}$ \\
\hline $\begin{array}{l}\text { Countries } \\
\text { Included }\end{array}$ & $\begin{array}{c}\text { ALL } \\
\text { COUNTRIES }\end{array}$ & & \\
\hline logt Test & 10.096 & & \\
\hline
\end{tabular}


Table 3: Club Convergence: Consumer Goods Index

\begin{tabular}{|c|c|c|c|c|c|c|c|}
\hline \multicolumn{8}{|l|}{ Level } \\
\hline Club Type & $\begin{array}{l}\text { Only One } \\
\text { Club }\end{array}$ & $\begin{array}{c}\text { First Convergence } \\
\text { Club }\end{array}$ & $\begin{array}{c}\text { Second } \\
\text { Convergence } \\
\text { Club } \\
\end{array}$ & $\begin{array}{c}\text { Third Convergence } \\
\text { Club }\end{array}$ & $\begin{array}{c}\text { Fourth } \\
\text { Convergence } \\
\text { Club } \\
\end{array}$ & $\begin{array}{c}\text { Fifth } \\
\text { Convergence } \\
\text { Club } \\
\end{array}$ & $\begin{array}{c}\text { Not } \\
\text { Converging } \\
\text { Countries } \\
\end{array}$ \\
\hline $\begin{array}{l}\text { Countries } \\
\text { Included }\end{array}$ & $\begin{array}{c}\text { ALL } \\
\text { COUNTRIES }\end{array}$ & $\begin{array}{c}\text { BRA, CHN, COL, } \\
\text { DNK, FRA, DEU, GRC, } \\
\text { IND, IDN, JPN, LUX, } \\
\text { NLD, NOR, PAK, SGP, } \\
\text { ZAF, ESP, SWE, CHE }\end{array}$ & $\begin{array}{l}\text { CAN, CHL, } \\
\text { HUN, ITA, } \\
\text { KOR, MYS, } \\
\text { PER, TUR, } \\
\text { UK, US }\end{array}$ & $\begin{array}{l}\text { ARG, AUT, CYP, } \\
\text { CZE, MEX, PHL, } \\
\text { PRT, THA }\end{array}$ & & & IRL \\
\hline $\log t$ Test & -680.701 & 2.263 & -0.605 & -0.377 & & & \\
\hline \multicolumn{8}{|l|}{ Volatility } \\
\hline Club Type & $\begin{array}{l}\text { Only One } \\
\text { Club }\end{array}$ & $\begin{array}{c}\text { First Convergence } \\
\text { Club }\end{array}$ & $\begin{array}{c}\text { Second } \\
\text { Convergence } \\
\text { Club } \\
\end{array}$ & $\begin{array}{c}\text { Third Convergence } \\
\text { Club }\end{array}$ & $\begin{array}{c}\text { Fourth } \\
\text { Convergence } \\
\text { Club } \\
\end{array}$ & $\begin{array}{c}\text { Fifth } \\
\text { Convergence } \\
\text { Club } \\
\end{array}$ & $\begin{array}{c}\text { Not } \\
\text { Converging } \\
\text { Countries } \\
\end{array}$ \\
\hline $\begin{array}{l}\text { Countries } \\
\text { Included }\end{array}$ & $\begin{array}{c}\text { ALL } \\
\text { COUNTRIES }\end{array}$ & $\begin{array}{l}\text { AUT, BRA, CHN, CZE, } \\
\text { GRC, IDN, NOR, PRT, } \\
\text { SGP, TUR }\end{array}$ & $\begin{array}{l}\text { MYS, PAK, } \\
\text { PHL, THA }\end{array}$ & $\begin{array}{l}\text { CAN, CHL, COL, } \\
\text { CYP, DNK, FRA, } \\
\text { DEU, IND, ITA, } \\
\text { JPN, KOR, LUX, } \\
\text { MEX, NLD, PER, } \\
\text { ZAF, SWE, CHE, } \\
\text { UK, US }\end{array}$ & HUN, ESP & ARG, IRL & \\
\hline $\log t$ Test & -1.943 & 15.016 & -1.286 & 1.035 & -1.637 & 6.640 & \\
\hline
\end{tabular}

Note: See Table 1. The 38 countries in this table include Argentina, Austria, Brazil, Canada, Chile, China, Colombia, Cyprus, the Czech Republic, Denmark, France, Germany, Greece, Hungary, India, Indonesia, Ireland, Italy, Japan, Korea, Luxembourg, Malaysia, Mexico, the Netherlands, Norway, Pakistan, Peru, the Philippines, Portugal, Singapore, South Africa, Spain, Sweden, Switzerland, Thailand, Turkey, the United Kingdom, and the United States. 
Table 4: $\quad$ Club Convergence: Consumer Services Index

\begin{tabular}{|c|c|c|c|c|c|}
\hline \multicolumn{6}{|l|}{ Level } \\
\hline Club Type & $\begin{array}{l}\text { Only One } \\
\text { Club }\end{array}$ & $\begin{array}{c}\text { First } \\
\text { Convergence } \\
\text { Club } \\
\end{array}$ & $\begin{array}{c}\text { Second } \\
\text { Convergence } \\
\text { Club } \\
\end{array}$ & $\begin{array}{c}\text { Third Convergence } \\
\text { Club }\end{array}$ & $\begin{array}{c}\text { Fourth } \\
\text { Convergence } \\
\text { Club } \\
\end{array}$ \\
\hline $\begin{array}{l}\text { Countries } \\
\text { Included }\end{array}$ & $\begin{array}{c}\text { ALL } \\
\text { COUNTRIES }\end{array}$ & $\begin{array}{l}\text { ARG, BEL, CHL, } \\
\text { CHN, COL, } \\
\text { GRC, IRL, NOR, } \\
\text { ZAF, SWE }\end{array}$ & $\begin{array}{c}\text { CAN, FIN, } \\
\text { HUN, ISR, } \\
\text { MEX, NLD, } \\
\text { SGP, CHE, US }\end{array}$ & $\begin{array}{l}\text { CYP, FRA, KOR, } \\
\text { MYS, DEU, IND, ITA, } \\
\text { JPN, LUX, PRT, ESP, } \\
\text { TUR, UK }\end{array}$ & $\begin{array}{l}\text { AUT, IDN, } \\
\text { PAK, PHL, } \\
\text { THA }\end{array}$ \\
\hline $\log t$ Test & -12.425 & 4.070 & 7.821 & 0.347 & -1.570 \\
\hline \multicolumn{6}{|l|}{ Volatility } \\
\hline Club Type & $\begin{array}{l}\text { Only One } \\
\text { Club }\end{array}$ & $\begin{array}{c}\text { First } \\
\text { Convergence } \\
\text { Club } \\
\end{array}$ & $\begin{array}{c}\text { Second } \\
\text { Convergence Club }\end{array}$ & $\begin{array}{c}\text { Third } \\
\text { Convergence } \\
\text { Club } \\
\end{array}$ & $\begin{array}{c}\text { Fourth } \\
\text { Convergence } \\
\text { Club }\end{array}$ \\
\hline $\begin{array}{l}\text { Countries } \\
\text { Included }\end{array}$ & $\begin{array}{c}\text { ALL } \\
\text { COUNTRIES }\end{array}$ & & & & \\
\hline $\log t$ Test & 36.042 & & & & \\
\hline \multicolumn{6}{|c|}{$\begin{array}{l}\text { Note: See Table } 1 \text {. The } 37 \text { countries in this table include Argentina, Austria, Belgium, Canada, Chile, China, } \\
\text { Colombia, Cyprus, Finland, France, Germany, Greece, Hungary, India, Indonesia, Ireland, Israel, Italy, } \\
\text { Japan, Korea, Luxembourg, Malaysia, Mexico, the Netherlands, Norway, Pakistan, the Philippines, } \\
\text { Portugal, Singapore, South Africa, Spain, Sweden, Switzerland, Thailand, Turkey, the United Kingdom, } \\
\text { and the United States. }\end{array}$} \\
\hline
\end{tabular}

Table 5: $\quad$ Club Convergence: Financials Index

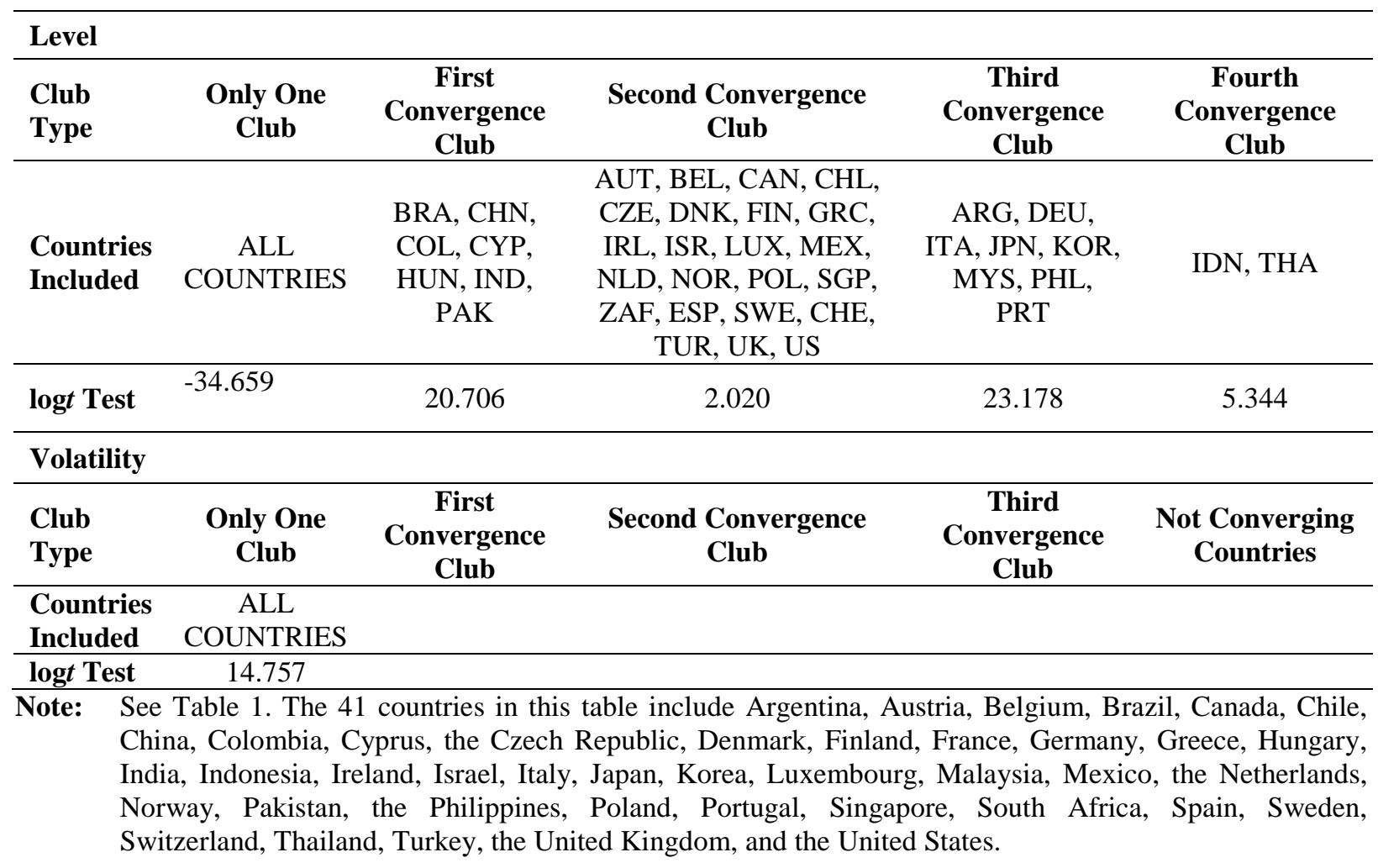


Table 6: $\quad$ Club Convergence: Healthcare Index

\begin{tabular}{|c|c|c|c|c|}
\hline \multicolumn{5}{|l|}{ Level } \\
\hline Club Type & $\begin{array}{l}\text { Only One } \\
\text { Club }\end{array}$ & First Convergence Club & Second Convergence Club & $\begin{array}{l}\text { Not Converging } \\
\text { Countries }\end{array}$ \\
\hline $\begin{array}{l}\text { Countries } \\
\text { Included }\end{array}$ & $\begin{array}{c}\text { ALL } \\
\text { COUNTRIES }\end{array}$ & $\begin{array}{l}\text { AUT, BEL, DNK, DEU, } \\
\text { ISR, KOR, PAK, ESP, SWE, } \\
\text { TUR }\end{array}$ & $\begin{array}{l}\text { CAN, FIN, FRA, HUN, } \\
\text { IND, IDN, IRL, ITA, JPN, } \\
\text { NLD, PRT, SGP, ZAF, } \\
\text { CHE, THA, UK, US } \\
\end{array}$ & \\
\hline $\log t$ Test & -15.035 & -1.618 & -1.234 & \\
\hline \multicolumn{5}{|l|}{ Volatility } \\
\hline Club Type & $\begin{array}{l}\text { Only One } \\
\text { Club }\end{array}$ & First Convergence Club & Second Convergence Club & $\begin{array}{l}\text { Not Converging } \\
\text { Countries }\end{array}$ \\
\hline $\begin{array}{l}\text { Countries } \\
\text { Included }\end{array}$ & $\begin{array}{c}\text { ALL } \\
\text { COUNTRIES }\end{array}$ & $\begin{array}{l}\text { AUT, BEL, CAN, DNK, } \\
\text { FIN, FRA, DEU, HUN, IND, } \\
\text { IDN, IRL, ISR, ITA, JPN, } \\
\text { KOR, NLD, PAK, SGP, } \\
\text { ZAF, ESP, SWE, CHE, } \\
\text { THA, TUR, UK, US }\end{array}$ & & POR \\
\hline $\log t$ Test & -15.641 & 22.204 & & \\
\hline Note: Sef & $\begin{array}{l}\text { ble } 1 \text {. The } 27 \\
\text { ny, Hungary, } \\
\text { al, Singapore, } \\
\text { United States. }\end{array}$ & $\begin{array}{l}\text { untries in this table include A } \\
\text { dia, Indonesia, Ireland, Israe } \\
\text { uth Africa, Spain, Sweden, S }\end{array}$ & $\begin{array}{l}\text { stria, Belgium, Canada, Denn } \\
\text { Italy, Japan, Korea, the I } \\
\text { vitzerland, Thailand, Turkey, }\end{array}$ & $\begin{array}{l}\text { rk, Finland, France } \\
\text { therlands, Pakistan } \\
\text { e United Kingdom }\end{array}$ \\
\hline
\end{tabular}

Table 7: $\quad$ Club Convergence: Industrial Index

\begin{tabular}{|c|c|c|c|c|c|}
\hline \multicolumn{6}{|l|}{ Level } \\
\hline Club Type & $\begin{array}{l}\text { Only One } \\
\text { Club }\end{array}$ & $\begin{array}{c}\text { First } \\
\text { Convergence } \\
\text { Club }\end{array}$ & $\begin{array}{c}\text { Second } \\
\text { Convergence } \\
\text { Club }\end{array}$ & Third Convergence Club & $\begin{array}{c}\text { Fourth } \\
\text { Convergence } \\
\text { Club }\end{array}$ \\
\hline $\begin{array}{l}\text { Countries } \\
\text { Included }\end{array}$ & $\begin{array}{c}\text { ALL } \\
\text { COUNTRIES }\end{array}$ & $\begin{array}{l}\text { BRA, GRC, } \\
\text { IND, IDN, } \\
\text { KOR, PER }\end{array}$ & $\begin{array}{l}\text { CHN, CZE, } \\
\text { FIN, IRL, } \\
\text { CHE }\end{array}$ & $\begin{array}{l}\text { AUT, BEL, CAN, CHL, } \\
\text { DNK, FRA, DEU, ISR, JPN, } \\
\text { NLD, NOR, PHL, PRT, } \\
\text { SGP, ZAF, ESP, SWE, TUR, } \\
\text { UK, US }\end{array}$ & $\begin{array}{l}\text { ARG, CYP, } \\
\text { ITA, LUX, } \\
\text { MYS, MEX, } \\
\text { PAK, THA }\end{array}$ \\
\hline $\log t$ Test & -52.669 & 45.474 & 1.863 & & 1.046 \\
\hline \multicolumn{6}{|l|}{ Volatility } \\
\hline Club Type & $\begin{array}{l}\text { Only One } \\
\text { Club }\end{array}$ & $\begin{array}{c}\text { First } \\
\text { Convergence } \\
\text { Club } \\
\end{array}$ & $\begin{array}{c}\text { Second } \\
\text { Convergence } \\
\text { Club } \\
\end{array}$ & Third Convergence Club & $\begin{array}{c}\text { Fourth } \\
\text { Convergence } \\
\text { Club } \\
\end{array}$ \\
\hline $\begin{array}{l}\text { Countries } \\
\text { Included }\end{array}$ & $\begin{array}{c}\text { ALL } \\
\text { COUNTRIES }\end{array}$ & & & & \\
\hline logt Test & 29.562 & & & & \\
\hline \multicolumn{6}{|c|}{$\begin{array}{l}\text { Note: See Table 1. The } 39 \text { countries in this table include Argentina, Austria, Belgium, Brazil, Canada, Chile, } \\
\text { China, Cyprus, the Czech Republic, Denmark, Finland, France, Germany, Greece, India, Indonesia, Ireland, } \\
\text { Israel, Italy, Japan, Korea, Luxembourg, Malaysia, Mexico, the Netherlands, Norway, Pakistan, Peru, the } \\
\text { Philippines, Portugal, Singapore, South Africa, Spain, Sweden, Switzerland, Thailand, Turkey, the United } \\
\text { Kingdom, and the United States. }\end{array}$} \\
\hline
\end{tabular}


Table 8: $\quad$ Club Convergence: Oil-Gas Index

\begin{tabular}{|c|c|c|c|c|c|c|}
\hline & Level & & & & & \\
\hline $\begin{array}{l}\text { Club } \\
\text { Type }\end{array}$ & $\begin{array}{l}\text { Only One } \\
\text { Club }\end{array}$ & $\begin{array}{c}\text { First } \\
\text { Convergence } \\
\text { Club }\end{array}$ & $\begin{array}{c}\text { Second } \\
\text { Convergence } \\
\text { Club }\end{array}$ & $\begin{array}{c}\text { Third } \\
\text { Convergence } \\
\text { Club }\end{array}$ & $\begin{array}{c}\text { Fourth } \\
\text { Convergence } \\
\text { Club }\end{array}$ & $\begin{array}{c}\text { Not } \\
\text { Converging } \\
\text { Countries }\end{array}$ \\
\hline $\begin{array}{l}\text { Countries } \\
\text { Included }\end{array}$ & $\begin{array}{c}\text { ALL } \\
\text { COUNTRIES }\end{array}$ & $\begin{array}{l}\text { AUT, BRA, } \\
\text { COL, CZE, } \\
\text { IRL }\end{array}$ & $\begin{array}{l}\text { CAN, FRA, ISR, } \\
\text { ITA, KOR, NLD, } \\
\text { NOR, SGP, ZAF, } \\
\text { ESP, THA, UK, } \\
\text { US }\end{array}$ & $\begin{array}{l}\text { CHL, IND, } \\
\text { PAK }\end{array}$ & $\begin{array}{l}\text { ARG, JPN, } \\
\text { MYS, PHL, } \\
\text { TUR }\end{array}$ & LUX \\
\hline \multirow[t]{2}{*}{$\log t$ Test } & -42.766 & 3.945 & 3.645 & 10.064 & 1.186 & \\
\hline & Volatility & & & & & \\
\hline $\begin{array}{l}\text { Club } \\
\text { Type }\end{array}$ & $\begin{array}{l}\text { Only One } \\
\text { Club }\end{array}$ & $\begin{array}{c}\text { First } \\
\text { Convergence } \\
\text { Club }\end{array}$ & $\begin{array}{c}\text { Second } \\
\text { Convergence } \\
\text { Club }\end{array}$ & $\begin{array}{c}\text { Third } \\
\text { Convergence } \\
\text { Club }\end{array}$ & $\begin{array}{c}\text { Fourth } \\
\text { Convergence } \\
\text { Club }\end{array}$ & $\begin{array}{c}\text { Not } \\
\text { Converging } \\
\text { Countries }\end{array}$ \\
\hline $\begin{array}{l}\text { Countries } \\
\text { Included }\end{array}$ & $\begin{array}{c}\text { ALL } \\
\text { COUNTRIES } \\
\end{array}$ & & & & & \\
\hline $\log t$ Test & 15.573 & & & & & \\
\hline Note: See & $\begin{array}{l}\text { able } 1 \text {. The } 27 \\
\text { Republic, Fra } \\
\text { ay, Pakistan, th } \\
\text { e United State }\end{array}$ & $\begin{array}{l}\text { untries in th } \\
\text {, India, Irel } \\
\text { Philippines, }\end{array}$ & $\begin{array}{l}\text { ble include Arge } \\
\text { Israel, Italy, Jap } \\
\text { gapore, South Af }\end{array}$ & $\begin{array}{l}\text { a, Austria, B } \\
\text { Korea, Luxer } \\
\text {, Spain, Thai }\end{array}$ & $\begin{array}{l}\text {, Canada, Cl } \\
\text { arg, Malaysi } \\
\text { Turkey, the }\end{array}$ & $\begin{array}{l}\text { Colombia, the } \\
\text { le Netherlands, } \\
\text { ited Kingdom, }\end{array}$ \\
\hline
\end{tabular}

Table 9: Club Convergence: Technology Index

\begin{tabular}{|c|c|c|c|c|c|}
\hline Level & & & & & \\
\hline Club Type & $\begin{array}{l}\text { Only One } \\
\text { Club }\end{array}$ & $\begin{array}{c}\text { First } \\
\text { Convergence } \\
\text { Club } \\
\end{array}$ & $\begin{array}{c}\text { Second } \\
\text { Convergence } \\
\text { Club } \\
\end{array}$ & $\begin{array}{c}\text { Third } \\
\text { Convergence } \\
\text { Club } \\
\end{array}$ & $\begin{array}{l}\text { Not Converging } \\
\text { Countries }\end{array}$ \\
\hline $\begin{array}{l}\text { Countries } \\
\text { Included }\end{array}$ & $\begin{array}{c}\text { ALL } \\
\text { COUNTRIES }\end{array}$ & BEL, FIN & $\begin{array}{l}\text { NLD, CHE, TUR, } \\
\text { US }\end{array}$ & $\begin{array}{l}\text { CAN, JPN, NOR, } \\
\text { SWE, UK }\end{array}$ & $\begin{array}{c}\text { CZE, FRA,DEU, } \\
\text { IND, ISR, ITA, } \\
\text { SGP, THA } \\
\end{array}$ \\
\hline logt Test & -34.433 & 1.200 & 2.887 & 19.891 & -37.209 \\
\hline \multicolumn{6}{|l|}{ Volatility } \\
\hline Club Type & $\begin{array}{l}\text { Only One } \\
\text { Club }\end{array}$ & $\begin{array}{c}\text { First } \\
\text { Convergence } \\
\text { Club } \\
\end{array}$ & $\begin{array}{c}\text { Second } \\
\text { Convergence } \\
\text { Club }\end{array}$ & $\begin{array}{c}\text { Third } \\
\text { Convergence } \\
\text { Club } \\
\end{array}$ & $\begin{array}{l}\text { Not Converging } \\
\text { Countries }\end{array}$ \\
\hline $\begin{array}{l}\text { Countries } \\
\text { Included }\end{array}$ & $\begin{array}{c}\text { ALL } \\
\text { COUNTRIES }\end{array}$ & $\begin{array}{c}\text { CAN, IND, NOR, } \\
\text { SGP, SWE, CHE, } \\
\text { THA, TUR }\end{array}$ & $\begin{array}{l}\text { FIN, ISR, JPN, } \\
\text { NLD, }\end{array}$ & $\begin{array}{l}\text { BEL, FRA, DEU, } \\
\text { ITA, UK, US }\end{array}$ & CZE \\
\hline logt Test & -11.279 & 44.592 & 22.980 & 21.974 & \\
\hline
\end{tabular}


Table 10: Club Convergence: Telecommunications Index

\begin{tabular}{|c|c|c|c|c|c|}
\hline \multicolumn{6}{|l|}{ Level } \\
\hline Club Type & $\begin{array}{l}\text { Only One } \\
\text { Club }\end{array}$ & $\begin{array}{c}\text { First } \\
\text { Convergence } \\
\text { Club }\end{array}$ & Second Convergence Club & $\begin{array}{c}\text { Third } \\
\text { Convergence } \\
\text { Club }\end{array}$ & $\begin{array}{c}\text { Not } \\
\text { Converging } \\
\text { Countries }\end{array}$ \\
\hline $\begin{array}{l}\text { Countries } \\
\text { Included }\end{array}$ & $\begin{array}{c}\text { ALL } \\
\text { COUNTRIES }\end{array}$ & $\begin{array}{l}\text { BEL, IND, } \\
\text { ISR, MEX, } \\
\text { PER, ESP, } \\
\text { SWE }\end{array}$ & $\begin{array}{l}\text { ARG, BRA, CAN, CHL, } \\
\text { DEU, ITA, JPN, KOR, } \\
\text { MYS, NLD, PHL, SGP, } \\
\text { THA, TUR, UK, US }\end{array}$ & & \\
\hline $\log t$ Test & -11.873 & 6.325 & -1.108 & & \\
\hline \multicolumn{6}{|l|}{ Volatility } \\
\hline Club Type & $\begin{array}{l}\text { Only One } \\
\text { Club }\end{array}$ & $\begin{array}{c}\text { First } \\
\text { Convergence } \\
\text { Club } \\
\end{array}$ & Second Convergence Club & $\begin{array}{c}\text { Third } \\
\text { Convergence } \\
\text { Club } \\
\end{array}$ & $\begin{array}{c}\text { Fourth } \\
\text { Convergence } \\
\text { Club } \\
\end{array}$ \\
\hline $\begin{array}{l}\text { Countries } \\
\text { Included }\end{array}$ & $\begin{array}{c}\text { ALL } \\
\text { COUNTRIES }\end{array}$ & $\begin{array}{l}\text { IND, ITA, } \\
\text { MEX, PER, } \\
\text { TUR, }\end{array}$ & CHL, ISR, MYS, SWE, US & $\begin{array}{c}\text { ARG, PHL, } \\
\text { THA }\end{array}$ & $\begin{array}{l}\text { BEL, BRA, } \\
\text { CAN, DEU, } \\
\text { JPN, KOR, } \\
\text { NLD, SGP, } \\
\text { ESP, UK }\end{array}$ \\
\hline $\log t$ Test & -38.001 & 5.760 & 27.521 & 1.620 & 93.721 \\
\hline
\end{tabular}

Table 11 Club Convergence Utilities Index

\begin{tabular}{|c|c|c|c|}
\hline \multicolumn{4}{|l|}{ Level } \\
\hline Club Type & $\begin{array}{l}\text { Only One } \\
\text { Club }\end{array}$ & First Convergence Club & Second Convergence Club \\
\hline $\begin{array}{l}\text { Countries } \\
\text { Included }\end{array}$ & $\begin{array}{c}\text { ALL } \\
\text { COUNTRIES }\end{array}$ & $\begin{array}{l}\text { AUT, BEL, CAN, CHL, COL, } \\
\text { CZE, DEU, IND, ITA, LUX, } \\
\text { NOR, ESP, CHE, UK, US }\end{array}$ & $\begin{array}{l}\text { ARG, BRA, HUN, JPN, KOR, } \\
\text { MYS, PAK, PHL, TUR }\end{array}$ \\
\hline logt Test & -23.375 & 0.193 & 21.375 \\
\hline \multicolumn{4}{|l|}{ Volatility } \\
\hline Club Type & $\begin{array}{l}\text { Only One } \\
\text { Club }\end{array}$ & First Convergence Club & Second Convergence Club \\
\hline $\begin{array}{l}\text { Countries } \\
\text { Included }\end{array}$ & $\begin{array}{c}\text { ALL } \\
\text { COUNTRIES }\end{array}$ & & \\
\hline logt Test & 20.088 & & \\
\hline $\begin{array}{ll}\text { Note: } & \text { See } \\
& \text { Canz } \\
& \text { Luxe } \\
& \text { Unit }\end{array}$ & $\begin{array}{l}\text { ble } 1 \text {. The } 24 \\
\text {, Chile, Coloml } \\
\text { bourg, Malaysi } \\
\text { Kingdom, and t }\end{array}$ & $\begin{array}{l}\text { ountries in this table include } \\
\text {, the Czech Republic, Germany } \\
\text { Norway, Pakistan, the Philipp } \\
\text { United States. }\end{array}$ & $\begin{array}{l}\text { tina, Austria, Belgium, Brazil, } \\
\text { gary, India, Italy, Japan, Korea, } \\
\text { Spain, Switzerland, Turkey, the }\end{array}$ \\
\hline
\end{tabular}


Table 12: $\quad$ Club Convergence: Aero-Defence Index

\begin{tabular}{|c|c|c|c|c|}
\hline \multicolumn{5}{|l|}{ Level } \\
\hline Club Type & $\begin{array}{l}\text { Only One } \\
\text { Club }\end{array}$ & $\begin{array}{c}\text { First } \\
\text { Convergence } \\
\text { Club } \\
\end{array}$ & $\begin{array}{c}\text { Second } \\
\text { Convergence } \\
\text { Club } \\
\end{array}$ & $\begin{array}{l}\text { Nonconverging } \\
\text { countries }\end{array}$ \\
\hline $\begin{array}{l}\text { Countries } \\
\text { Included }\end{array}$ & $\begin{array}{c}\text { ALL } \\
\text { COUNTRIES }\end{array}$ & FRA, UK, US & BRA, CAN, ITA & IND \\
\hline logt Test & -39.480 & 2.167 & 0.151 & \\
\hline \multicolumn{5}{|l|}{ Volatility } \\
\hline Club Type & $\begin{array}{l}\text { Only One } \\
\text { Club }\end{array}$ & $\begin{array}{c}\text { First } \\
\text { Convergence } \\
\text { Club } \\
\end{array}$ & $\begin{array}{c}\text { Second } \\
\text { Convergence } \\
\text { Club } \\
\end{array}$ & \\
\hline $\begin{array}{l}\text { Countries } \\
\text { Included }\end{array}$ & $\begin{array}{c}\text { ALL } \\
\text { COUNTRIES } \\
\end{array}$ & & & \\
\hline logt Test & 115.121 & & & \\
\hline
\end{tabular}

Table 13: Club Convergence: Construction Materials Index

\begin{tabular}{|c|c|c|c|c|c|}
\hline & Level & & & & \\
\hline Club Type & $\begin{array}{l}\text { Only One } \\
\text { Club }\end{array}$ & $\begin{array}{c}\text { First } \\
\text { Convergence } \\
\text { Club }\end{array}$ & Second Convergence Club & $\begin{array}{c}\text { Third } \\
\text { Convergence } \\
\text { Club }\end{array}$ & $\begin{array}{c}\text { Not } \\
\text { Converging } \\
\text { Countries }\end{array}$ \\
\hline $\begin{array}{l}\text { Countries } \\
\text { Included }\end{array}$ & $\begin{array}{c}\text { ALL } \\
\text { COUNTRIES }\end{array}$ & $\begin{array}{l}\text { CHN, DNK, FIN, } \\
\text { IND, IRL, NOR, } \\
\text { PHL, ZAF, ESP, } \\
\text { TUR }\end{array}$ & $\begin{array}{l}\text { AUT, BEL, CAN, COL, } \\
\text { FRA, DEU, GRC, IDN, ISR, } \\
\text { ITA, JPN, KOR, MEX, NLD, } \\
\text { PER, POL, PRT, SWE, CHE, } \\
\text { THA, UK, US }\end{array}$ & ARG, MYS & CYP \\
\hline logt Test & -47.499 & 0.667 & 3.946 & -0.107 & \\
\hline \multicolumn{6}{|c|}{ Volatility } \\
\hline Club Type & $\begin{array}{l}\text { Only One } \\
\text { Club }\end{array}$ & $\begin{array}{c}\text { First } \\
\text { Convergence } \\
\text { Club }\end{array}$ & Second Convergence Club & & $\begin{array}{c}\text { Not } \\
\text { Converging } \\
\text { Countries }\end{array}$ \\
\hline $\begin{array}{l}\text { Countries } \\
\text { Included }\end{array}$ & $\begin{array}{c}\text { ALL } \\
\text { COUNTRIES }\end{array}$ & & & & \\
\hline logt Test & 19.120 & & & & \\
\hline \multicolumn{6}{|c|}{$\begin{array}{l}\text { See Table 1. The } 35 \text { countries in this table include Argentina, Austria, Belgium, Canada, China, } \\
\text { Colombia, Cyprus, Denmark, Finland, France, Germany, Greece, India, Indonesia, Ireland, Israel, } \\
\text { Italy, Japan, Korea, Malaysia, Mexico, the Netherlands, Norway, Peru, the Philippines, Poland, } \\
\text { Portugal, South Africa, Spain, Sweden, Switzerland, Thailand, Turkey, the United Kingdom, and the } \\
\text { United States. }\end{array}$} \\
\hline
\end{tabular}


Table 14: Club Convergence: Electronics Index

\begin{tabular}{|c|c|c|c|c|c|}
\hline \multicolumn{6}{|l|}{ Level } \\
\hline Club Type & $\begin{array}{l}\text { Only One } \\
\text { Club }\end{array}$ & $\begin{array}{c}\text { First } \\
\text { Convergence } \\
\text { Club }\end{array}$ & $\begin{array}{c}\text { Second } \\
\text { Convergence } \\
\text { Club }\end{array}$ & $\begin{array}{c}\text { Third Convergence } \\
\text { Club }\end{array}$ & $\begin{array}{c}\text { Fourth } \\
\text { Convergence } \\
\text { Club }\end{array}$ \\
\hline $\begin{array}{l}\text { Countries } \\
\text { Included }\end{array}$ & $\begin{array}{c}\text { ALL } \\
\text { COUNTRIES }\end{array}$ & CHN, IND, SWE & $\begin{array}{l}\text { CAN, ITA, NLD, } \\
\text { CHE, US }\end{array}$ & $\begin{array}{l}\text { FIN, FRA, DEU, } \\
\text { JPN, KOR, THA }\end{array}$ & $\begin{array}{l}\text { BEL, DNK, } \\
\text { SGP, UK }\end{array}$ \\
\hline logt Test & -18.224 & 28.018 & 8.150 & -0.743 & 3.041 \\
\hline \multicolumn{6}{|l|}{ Volatility } \\
\hline Club Type & $\begin{array}{l}\text { Only One } \\
\text { Club }\end{array}$ & $\begin{array}{c}\text { First Convergence } \\
\text { Club }\end{array}$ & $\begin{array}{c}\text { Second } \\
\text { Convergence Club }\end{array}$ & $\begin{array}{c}\text { Third } \\
\text { Convergence } \\
\text { Club } \\
\end{array}$ & $\begin{array}{c}\text { Fourth } \\
\text { Convergence } \\
\text { Club } \\
\end{array}$ \\
\hline $\begin{array}{l}\text { Countries } \\
\text { Included }\end{array}$ & $\begin{array}{c}\text { ALL } \\
\text { COUNTRIES }\end{array}$ & & & & \\
\hline $\log t$ Test & 19.408 & & & & \\
\hline $\mathrm{Se}$ & India, It & tod St & nclude Bel & $\begin{array}{l}\text { China, D } \\
\text { weden, } S\end{array}$ & $\begin{array}{l}\text { inland } \\
\text { Thai }\end{array}$ \\
\hline
\end{tabular}

Table 15: Club Convergence: Engineering Index

\begin{tabular}{|c|c|c|c|c|}
\hline \multicolumn{5}{|l|}{ Level } \\
\hline Club Type & $\begin{array}{l}\text { Only One } \\
\text { Club }\end{array}$ & First Convergence Club & $\begin{array}{c}\text { Second } \\
\text { Convergence Club }\end{array}$ & $\begin{array}{c}\text { Third Convergence } \\
\text { Club }\end{array}$ \\
\hline $\begin{array}{l}\text { Countries } \\
\text { Included }\end{array}$ & $\begin{array}{c}\text { ALL } \\
\text { COUNTRIES }\end{array}$ & FRA, GRC, IDN, KOR, PER & $\begin{array}{l}\text { AUT, CHN, FIN, } \\
\text { DEU, IND, NLD, } \\
\text { PAK, ESP, SWE, } \\
\text { CHE, UK, US }\end{array}$ & $\begin{array}{l}\text { BEL, CAN, ITA, } \\
\text { JPN, NOR, SGP }\end{array}$ \\
\hline $\log t$ Test & -13.714 & 26.536 & 0.654 & 14.576 \\
\hline \multicolumn{5}{|l|}{ Volatility } \\
\hline Club Type & $\begin{array}{l}\text { Only One } \\
\text { Club }\end{array}$ & First Convergence Club & $\begin{array}{c}\text { Second } \\
\text { Convergence Club }\end{array}$ & $\begin{array}{c}\text { Third Convergence } \\
\text { Club }\end{array}$ \\
\hline $\begin{array}{l}\text { Countries } \\
\text { Included }\end{array}$ & $\begin{array}{c}\text { ALL } \\
\text { COUNTRIES } \\
\end{array}$ & & & \\
\hline $\log t$ Test & 26.609 & & & \\
\hline $\begin{array}{ll}\text { Note: } & \text { See } \\
& \text { Chin } \\
& \text { the I } \\
& \text { the U }\end{array}$ & $\begin{array}{l}\text { ble 1. The } 23 \\
\text { Finland, Franc } \\
\text { therlands, Norw } \\
\text { ited Kingdom, a }\end{array}$ & $\begin{array}{l}\text { tries in this table include } \mathrm{Al} \\
\text { armany, Greece, India, Indone } \\
\text { akistan, Peru, Singapore, Spa } \\
\text { e United States. }\end{array}$ & $\begin{array}{l}\text { Belgium, Canada, } \\
\text { Italy, Japan, Korea, } \\
\text { weden, Switzerland, }\end{array}$ & \\
\hline
\end{tabular}


Table 16: Club Convergence: General Industries Index

\begin{tabular}{|c|c|c|c|c|}
\hline \multicolumn{5}{|l|}{ Level } \\
\hline Club Type & $\begin{array}{l}\text { Only One } \\
\text { Club }\end{array}$ & $\begin{array}{c}\text { First Convergence } \\
\text { Club }\end{array}$ & Second Convergence Club & $\begin{array}{c}\text { Third Convergence } \\
\text { Club }\end{array}$ \\
\hline $\begin{array}{l}\text { Countries } \\
\text { Included }\end{array}$ & $\begin{array}{c}\text { ALL } \\
\text { COUNTRIES }\end{array}$ & ARG, CHN, KOR & $\begin{array}{l}\text { AUT, BEL, CAN, CHL, CZE, } \\
\text { DNK, DEU, GRC, JPN, MEX, } \\
\text { NLD, PAK, SGP, ZAF, CHE }\end{array}$ & $\begin{array}{l}\text { COL, FIN, ISR, ITA, } \\
\text { MYS, PHL, UK, US }\end{array}$ \\
\hline $\log t$ Test & -148.141 & 0.600 & -1.176 & 8.868 \\
\hline \multicolumn{5}{|l|}{ Volatility } \\
\hline Club Type & $\begin{array}{c}\text { Only One } \\
\text { Club }\end{array}$ & $\begin{array}{c}\text { First Convergence } \\
\text { Club }\end{array}$ & Second Convergence Club & $\begin{array}{c}\text { Third Convergence } \\
\text { Club }\end{array}$ \\
\hline $\begin{array}{l}\text { Countries } \\
\text { Included }\end{array}$ & $\begin{array}{c}\text { ALL } \\
\text { COUNTRIES } \\
\end{array}$ & & & \\
\hline logt Test & 6.287 & & & \\
\hline $\begin{array}{ll}\text { Note: } & \text { See } \\
& \text { Colo } \\
& \text { Mexi } \\
& \text { King }\end{array}$ & $\begin{array}{l}\text { ble } 1 \text {. The } 26 \\
\text { ia, the Czech } \\
\text {, the Netherl } \\
\mathrm{m} \text {, and the Un }\end{array}$ & $\begin{array}{l}\text { untries in this table } \\
\text { public, Denmark, Fi } \\
\text { s, Pakistan, the Ph } \\
\text { States. }\end{array}$ & $\begin{array}{l}\text { lude Argentina, Austria, Belg } \\
\text { d, Germany, Greece, Israel, It } \\
\text { ines, Singapore, South Afric }\end{array}$ & $\begin{array}{l}\text { Canada, Chile, China } \\
\text { apan, Korea, Malaysia } \\
\text { witzerland, the Unite }\end{array}$ \\
\hline
\end{tabular}

Table 17: Club Convergence: Services Index

\begin{tabular}{|c|c|c|c|c|c|}
\hline \multicolumn{6}{|l|}{ Level } \\
\hline Club Type & $\begin{array}{l}\text { Only One } \\
\text { Club }\end{array}$ & $\begin{array}{c}\text { First } \\
\text { Convergence } \\
\text { Club }\end{array}$ & $\begin{array}{c}\text { Second } \\
\text { Convergence Club }\end{array}$ & $\begin{array}{c}\text { Third } \\
\text { Convergence } \\
\text { Club }\end{array}$ & $\begin{array}{c}\text { Fourth } \\
\text { Convergence } \\
\text { Club }\end{array}$ \\
\hline $\begin{array}{l}\text { Countries } \\
\text { Included }\end{array}$ & $\begin{array}{c}\text { ALL } \\
\text { COUNTRIES }\end{array}$ & $\begin{array}{l}\text { ARG, CHN, } \\
\text { SWE }\end{array}$ & $\begin{array}{l}\text { DEU, IRL, LUX, } \\
\text { MYS, NLD, ESP }\end{array}$ & FRA, ZAF, CHE & $\begin{array}{l}\text { CAN, JPN, UK, } \\
\text { US }\end{array}$ \\
\hline $\log t$ Test & -15.437 & 6.285 & 1.927 & 12.419 & -1.416 \\
\hline \multicolumn{6}{|l|}{ Volatility } \\
\hline Club Type & $\begin{array}{l}\text { Only One } \\
\text { Club }\end{array}$ & $\begin{array}{c}\text { First } \\
\text { Convergence } \\
\text { Club }\end{array}$ & $\begin{array}{c}\text { Second } \\
\text { Convergence Club }\end{array}$ & $\begin{array}{c}\text { Third } \\
\text { Convergence } \\
\text { Club }\end{array}$ & $\begin{array}{c}\text { Fourth } \\
\text { Convergence } \\
\text { Club }\end{array}$ \\
\hline $\begin{array}{l}\text { Countries } \\
\text { Included }\end{array}$ & $\begin{array}{c}\text { ALL } \\
\text { COUNTRIES }\end{array}$ & CHN, LUX & $\begin{array}{l}\text { IRL, JPN, MYS, } \\
\text { NLD, ZAF }\end{array}$ & $\begin{array}{l}\text { ARG, FRA, ESP, } \\
\text { SWE, UK, US }\end{array}$ & CAN, DEU, CHE \\
\hline $\log t$ Test & -6.856 & -1.172 & 0.027 & 0.134 & 16.208 \\
\hline
\end{tabular}


Table 18: $\quad$ Club Convergence: Transport Index

\begin{tabular}{|c|c|c|c|}
\hline \multicolumn{4}{|l|}{ Level } \\
\hline Club Type & $\begin{array}{l}\text { Only One } \\
\text { Club }\end{array}$ & First Convergence Club & Second Convergence Club \\
\hline $\begin{array}{l}\text { Countries } \\
\text { Included }\end{array}$ & $\begin{array}{c}\text { ALL } \\
\text { COUNTRIES }\end{array}$ & $\begin{array}{c}\text { AUT, BEL, CAN, CHL, CHN, DNK, } \\
\text { FRA, DEU, IND, ITA, JPN, KOR, } \\
\text { MEX, NLD, NOR, PHL, SGP, ZAF, } \\
\text { ESP, UK, US }\end{array}$ & CYP, CZE, MYS, CHE, THA \\
\hline $\log t$ Test & -1.681 & 3.646 & 0.119 \\
\hline \multicolumn{4}{|l|}{ Volatility } \\
\hline Club Type & $\begin{array}{l}\text { Only One } \\
\text { Club }\end{array}$ & First Convergence Club & Second Convergence Club \\
\hline $\begin{array}{l}\text { Countries } \\
\text { Included }\end{array}$ & $\begin{array}{c}\text { ALL } \\
\text { COUNTRIES }\end{array}$ & $\begin{array}{l}\text { CHL, CHN, CYP, DNK, IND, JPN, } \\
\text { KOR, NOR, PHL, SGP, ESP, UK, US }\end{array}$ & $\begin{array}{l}\text { AUT, BEL, CAN, CZE, FRA, } \\
\text { DEU, ITA, MYS, MEX, NLD, } \\
\text { ZAF, CHE, THA }\end{array}$ \\
\hline $\log t$ Test & -18.929 & 8.932 & -0.025 \\
\hline $\begin{array}{l}\text { Tote: } \\
\text { See } \\
\text { the } \\
\text { Netl } \\
\text { Unit }\end{array}$ & $\begin{array}{l}\text { le } 1 \text {. The } 26 \mathrm{cc} \\
\text { ch Republic, D } \\
\text { ands, Norway, }\end{array}$ & $\begin{array}{l}\text { tries in this table include Austria, Belg } \\
\text { mark, France, Germany, India, Italy, J } \\
\text { e Philippines, Singapore, South Afric }\end{array}$ & $\begin{array}{l}\text { n, Canada, Chile, China, Cyprus } \\
\text { in, Korea, Malaysia, Mexico, th } \\
\text { pain, Switzerland, Thailand, th }\end{array}$ \\
\hline
\end{tabular}

